Article

\title{
Agritourism Initiatives in the Context of Continuous Out-Migration: Comparative Perspectives for the Alps and Chinese Mountain Regions
}

\author{
Thomas Dax ${ }^{1, *(\mathbb{D})}$, Dachang Zhang ${ }^{2}$ and Yanying Chen ${ }^{3}$ \\ 1 Federal Institute of Agricultural Economics, Rural and Mountain Research, 1030 Vienna, Austria \\ 2 Water and Eco Crisis Foundation, San Jose, CA 95014, USA \\ 3 Bijie Pilot Area Research Institute, Guizhou University of Engineering Science, Guizhou 551700, China \\ * Correspondence: thomas.dax@bab.bmnt.gv.at; Tel.: +43-1-71100-637528
}

Received: 29 April 2019; Accepted: 12 August 2019; Published: 15 August 2019

check for updates

\begin{abstract}
After World War II, the economic recovery of Western Europe implied a swift economic transition for all regions, including the area of the Alps, although affecting various parts at different paces and stages. The resulting out-migration led to population decline in some mountain valleys and regions since the 1950s. Such negative population development trends are widespread across mountain areas of the world, including China, where out-migration started after its rural reform in the 1970s. The effect was in some cases even more significant than in the Alps, with the first villages being deserted in the 1980s. Current estimations report about 380,000 rural villages in China being abandoned between 2000-2016, particularly in its mountain regions. While lower population densities might alleviate the pressures on ecology and contribute to environmental benefits, these movements aggravate a spiraling-down process of local economies and culture. In the Alps, many regions that were facing challenges of out-migration and economic weaknesses focused on local initiatives, including agritourism schemes that provided both economic incentives and stability to involved mountain farmers, and the continuation of local land management systems. However, China's interest for promoting rural action and tourism-oriented farm diversification only started more recently, with a range of rural tourism and agricultural tourism initiatives emerging. This paper focuses on lessons from successful initiatives in the Alps that might induce and strengthen China's search for elaborating agritourism activities in mountain areas. In consequence, agritourism might be assessed as a contribution to mitigate out-migration from mountain regions and a core element of the future sustainable development of the Alps and the Chinese countryside.
\end{abstract}

Keywords: definition of agritourism; comparative studies; rural development; sustainable tourism; mountain development; Alpine regions; Chinese mountains

\section{Introduction}

The global increase in tourism [1] and the recent boom in agritourism activities in many countries of the world [2] might lead to an understanding that tourism success could represent the main approach for also overcoming weaknesses of mountain regions. However, it might be important to analyze the background conditions, relevance, and effects of such developments. As the regional context and cultural foundations are different from country to country, and also quite divergent by individual regions, the types and features of agritourism differ substantially. These differences translate also in the search for capturing the phenomena of similar types of "rural tourism" development and the terminology and essence of the specificities of "agritourism" [3].

With respect to analyzing the effects of agritourism, an understanding of its linkage to both its agricultural production base and its spatial embeddedness is required. "Authentic" agritourism 
schemes [4,5], similar to those that have been elaborated in the Alps in Europe already since the late 19th century, are based on valuing the distinctness of experiencing leisure time in close relation to nature and to agricultural activities to which particularly urban population groups are more and more distant, or even alien. Therefore, the demand for this type of tourism is tightly linked to strengthening emotional ties to agricultural activities and to "awe" for natural features, which might imply a highly relevant contribution to pathways toward sustainable tourism trajectories [6]. The concept of atmosphere, which highlights the linkages of perceiving specific traits of agricultural practices with its integration into natural resources and landscape features [7], can serve as an instrument to highlight the increasing interest in agritourism activities in many countries of the world.

However, agritourism activities can only be realized and become effective on a regional scale if they are conceived as an economic activity of diversification of farming activities, sustaining the level of household incomes. Increasingly, interlinkages with the local and regional (tourism) economies have to be seen as an integrative part of their development. Particularly in remote areas, including mountain regions, islands, and other spaces of specific geographical contexts, such tourism activities could imply substantial effects on small-scale regional development and contribute to spatial strategies that nurture nature-based assets [8]. With regard to the development challenges of these regions, their contribution to cope with negative economic and demographic trends should not be neglected. As could be shown for some European mountain regions, trends of out-migration could be stopped, not least because of numerous regional development initiatives, including agritourism strategies $[9,10]$. Changes affecting migration trends are particularly due to indirect effects resulting from shifts in the attractiveness of those areas. This paper focuses on these challenges and comments on selected agritourism initiatives that aim at coping with such negative trends. By presenting approaches in various regions of China and relating them to lessons from developments in mountains of Europe where such activities look back on a long-term experience, useful insights for future adaptation might be derived.

The paper is based on the interest of Chinese rural, mountain regions in accessing mountain development approaches that put a specific focus on agritourism potential for raising farm income and impacting on regional development within the European Alps. As a research stay of the second author to a series of Alpine regions provided a number of useful examples from these regions, findings from analysis of the Alpine approaches will be used and synthesized for this paper. Against this backdrop, several innovative emerging examples from Chinese mountain regions will be highlighted to underscore the applicability of respective approaches in the Chinese context also. Hence, the transfer of implementation knowledge is not targeted at "transferring" the whole application, but rather underpins the need to address place-specific contexts and cultural divergences, institutional and governance requirements, the need for iterative processes, obstacles, and threats within the development of agritourism, and the need for a decisive place-sensitive strategy in such activities.

With the factual and cultural differences in mind, it seems highly important to expand on the dimension and specificities of the challenge in the Chinese context. The migration of rural labor to cities in China began at the end of 1978 during the period of reform and opening-up. The rapid urbanization process increased the migration of rural labor to cities so that China's urbanization rate exceeded $50 \%$ for the first time in 2011. In the period from 2001 to 2017, China's urban population had increased from 480 million to 813 million, and the ratio of rural permanent population to urban permanent population dropped significantly. It was forecasted that China will have another 150 million farmers moving from rural to urban areas by 2020 [11]. The forces driving rural population decline are particularly strong in China, where this process has been ongoing for decades, and a "rural revival is needed to counter urbanization" [11,12], and is visible throughout all the major regions of the globe.

As the result of farmers outflowing, villages are rapidly disappearing, with the first village being abandoned in the 1980s. According to the Chinese Bureau of Statistics, about 380,000 natural villages disappeared in China between 2000 (3.7 million) and 2016 (3.32 million), which means "65 villages disappear per day", especially in mountainous areas [12,13]. The disappearance of villages has significant implications also for the changes of local culture. Numerous examples reveal that with the 
outflow of the peasants, specific cultural elements have also gone (see e.g., the case of the mountain village Nankeng of Yongxiu County in northwestern Jiangxi Province, where a century-old martial culture to defend against foreign enemies has disappeared).

Many mountain regions in Europe also used to be characterized by weak economic performance and suffered from negative population trends. However, that assessment has to be differentiated through ascertaining whether in more accessible and/or prosperous regions mountain areas were characterized also by more positive demographic changes. Therefore, a place-specific analysis is required that looks beyond the final population balance, while also addressing its various components and territorial differences. Selecting mountain areas of population decline in Austria provides an interesting case where approximately one-third of rural areas have experienced substantial negative population change over the past decades [14]. Shrinking rural regions have consequently been highlighted as an emerging topic in European discussions of regional development [15]. The analysis of the Austrian situation of mountain regions stressed the persistence of the phenomenon in an inner-Alpine context (which has inspired the term of "Inner Peripheries") and highlighted that many initiatives are relevant in these regions that aim at impacting on the economic performance, income levels, and well-being patterns of the local population. From the project analysis, it is concluded that future approaches have to go beyond 'traditional' strategies of targeting economic growth, but need to focus on local participation, social innovation in line with technological development, and particularly establishing trust as a basis to effectively address well-being in the region.

Even if those recent studies only marginally referred to tourism development, the scope for agritouristic initiatives was a main preoccupation when mountain initiatives started several decades ago [9]. It should be highlighted that long-term concern for linking agricultural with tourism activities has brought about a wide net of agritourism structures, which is in place throughout these mountain regions with a particular influence on service provision, the attractiveness of the region, and linking land management and farm production to tourism options at local and regional levels. A more comprehensive view acknowledges the specific role of tourism in mountain regions [16] and the relevance of agritourism within strategies for sustainable tourism approaches [17]. However, with the ongoing population decline and problems regarding finding successors to agritouristic facilities, there is a renewed interest in strategic consideration for these tourism regions. Problems of diverse tourism intensity add to this concern and call for a holistic approach to regional policy development [18]. A synthesis of the long-lasting efforts to enhance agritourism in Austria was presented and discussed in a recent workshop [19] that outlined the numerous challenges and opportunities of this tourism form. It could provide findings from respective consumer services regarding whether this is an adapted type of tourism offer that largely meets the emerging demand for high-quality and, at the same time authentic, locally based tourism offers linked closely to farming activities, vernacular elements, food, outdoor sports, and nature. This practice reference reflects the theoretical considerations related to striving for agritourism implementation in various regional contexts [20] and with a wide set of country-specific implementation forms [21]. On the occasion of its 25th anniversary, the national association of agritourism in Austria boasts of hosting about 2 million guests every year, thereof 500,000 children, which is assumed to be highly important to convey the knowledge and experience of the farming world to (mostly) urban visitors [22].

Thus, linking demographic and urbanization trends with agritourism interests is a chance for mitigating population decline and shifting the values of urban and rural inhabitants toward a more balanced assessment that includes significant opportunities for high-quality agritourism developments. The pertinence of the issue is underlined by a recent resolution of the European Parliament [23], which refers to the importance of rural depopulation in these regions and "(e)mphasizes the need to support the further development of rural tourism and mountain agritourism while preserving the specificities of these areas, for example traditions and traditional local products, since tourism has a major social, economic and cultural impact" ([23], point 8). The conditions under which agritourism is a promising 
opportunity also for mountain farms and communities in China are at the core of the analytical interest of this article.

\section{Materials and Methods}

The analysis of this article is based on the intensive discussions of finding regional strategies that make use of agritourism initiatives to cope with out-migration in mountain regions. Given the long-term engagement of local and regional actors in the European Alps in elaborating adapted forms of agritourism and its wide-ranging application, these experiences are taken as an initial reference. A literature review of the usefulness of the concept and its implications for regional performance and demographic trends [17] is used to provide a framework for assessing the potential of respective activities. A number of types of different forms of sustainable tourism in mountain areas (Table 1) summarize the main concepts. Even if types might overlap to some extent, and differences between the contexts of mountain development in China and Europe are substantial, these build a framework for conceiving mountain tourism activities. Any attempt of "transferring" or "replicating" good practice examples will have to acknowledge the context-specificity and historical legacies in development work. Moreover, this paper seeks to concentrate on one of these rural tourism forms, i.e., agritourism activities as an emerging field of rural potential in mountain contexts of intensively changing societies such as those in China.

Table 1. Forms of sustainable tourism in mountain areas ([17], 12f.).

\begin{tabular}{|c|c|c|}
\hline Tourism Types & Main Characteristics & $\begin{array}{l}\text { Relevance for } \\
\text { Agritourism }\end{array}$ \\
\hline Rural tourism & $\begin{array}{l}\text { Location in rural areas, places of low population } \\
\text { density; open space and small communities }\end{array}$ & Overarching category \\
\hline Agritourism & $\begin{array}{c}\text { Existence of a working farm, realizing } \\
\text { supplemental income through agritourism } \\
\text { activities, services provided for enjoyment or } \\
\text { education of visitors }\end{array}$ & $\begin{array}{l}\text { "Authentic" form of } \\
\text { agritourism }\end{array}$ \\
\hline Nature tourism & Nature-based travel and tourism experiences & $\begin{array}{l}\text { Providing access to } \\
\text { nature experiences }\end{array}$ \\
\hline Ecotourism & $\begin{array}{l}\text { Sub-category of nature tourism aiming at } \\
\text { conservation of the environment and sustaining } \\
\text { the well-being of local people }\end{array}$ & $\begin{array}{l}\text { As above, with a specific } \\
\text { emphasis on ecological } \\
\text { benefits }\end{array}$ \\
\hline $\begin{array}{l}\text { Community-based } \\
\text { tourism }\end{array}$ & $\begin{array}{l}\text { Community acting as communal enterprise in } \\
\text { tourism planning and management, with specific } \\
\text { community-driven goals }\end{array}$ & $\begin{array}{l}\text { Place-specific cultural } \\
\text { traits and community as } \\
\text { driver for agritourism } \\
\text { cooperation }\end{array}$ \\
\hline Cultural tourism & $\begin{array}{l}\text { Linkages of tourism and cultural diversity at the } \\
\text { center; encourages dialogue between visitors and } \\
\text { hosts, cooperation, and heritage values. }\end{array}$ & $\begin{array}{l}\text { Historical background } \\
\text { and essence of activities } \\
\text { and strategies }\end{array}$ \\
\hline
\end{tabular}

Drawing on the experience of the long-term and most intensive application of the type of agritouristic development in the Alps, the basis of this scientific exchange is conducting extensive field visits, investigating various forms of application, and analyzing the various levels of institutional support structures in all the countries of the Alpine Convention [18,24]. With regard to the aim of this article, to investigate the contribution of agricultural initiatives to mitigate out-migration tendencies from mountain regions, a literature review on the analysis for the European situation and a series of case studies of selected types of agritourism application in China was carried out. The selected cases reflect some crucial examples of agritourism initiatives depicting the scope of action in this rapidly rising segment in China. Table 2 (see below) will indicate the relevance of the presented examples and link them to the specific aspects regarding the types of agritourism on offer that are available from a 
conceptual perspective. In these cases, the spatial analysis is crucial, as the development and success of initiatives is highly dependent on spatial interrelations to other areas, including lowland areas. In particular, with regard to demand for agritourism, the trans-regional view is particularly influential.

The main interest in observing and analyzing appropriate place-based initiatives at the local scale [25] is targeted at exploring not just challenges, but particularly the drivers for realizing the specific opportunities available in those regions. This should enhance strategy building for making use of potential for rural development in these regions by addressing local specificities and spatial interrelations [26]. There are specific benefits of agritourism initiatives that have close relationships with regional development options and performance [27]. In addition to the literature in Europe and other parts of the world, the scope for increasing the potential and demand for rural tourism in China, as well as that of its sub-types of farm-linked activities of agritourism [28], should be highlighted.

The analysis of the divergent set of approaches builds particularly on the long-lasting experience of agritourism, particularly in the Alps (e.g., $[8,18,29,30])$. Despite its historic roots, these are not limited to "traditional" approaches, but rather seek to adapt and up-take more recent changes and technological improvements and social learning. As such, the analysis reflects on the particular scope of activities, market, and technological dynamics, and the integration into the regional socio-ecological system (see [31,32]). The specific interest is to address implications for migration and indirect effects of agritourism on regional differentiation and local attractiveness. As a consequence, these initiatives build on and, at the same time, have implications for quality-of-life experiences in those mountain areas ([14]. A reflection of those interlinkages in the analysis of this article reviews the wide array of contributions in the field regarding arguing for a revised perspective on "shrinking rural regions" [15], in particular including mountain regions in all parts of the world.

Table 2. Types of agritourism activities $[19,27,33,34]$.

\begin{tabular}{|c|c|c|}
\hline Priority of Agritourism Offer & $\begin{array}{l}\text { Diversification Activities/ } \\
\text { Functional Relationship }\end{array}$ & $\begin{array}{c}\text { Main Relevance for Case } \\
\text { Studies (CS) }\end{array}$ \\
\hline Asset-based farm stay offer & $\begin{array}{ll}\text { - } & \text { Local architecture/vernacular assets } \\
\text { - } & \text { Farm buildings, sheds, and regional } \\
\text { settlement types } \\
\text { - } \quad \begin{array}{l}\text { Alpine pastures and mountain } \\
\text { farming attributes }\end{array}\end{array}$ & CS 1,2 \\
\hline Making use of farm produce & $\begin{array}{ll}\text { - } & \text { Observing farm production } \\
\text { - } & \text { Availability of farm produce for } \\
\text { catering of guests }\end{array}$ & CS $1,2,4$ \\
\hline $\begin{array}{l}\text { Building on regional farm } \\
\text { products/quality products }\end{array}$ & $\begin{array}{ll}\text { - } & \text { Tracing local/regional } \\
\text { (traditional) products } \\
\text { - } & \text { Mountain farm products labels } \\
\text { - } & \text { Products of geographical origin } \\
\text { - } & \text { Quality labels } \\
\text { - } & \text { Organic farm production }\end{array}$ & CS 4 \\
\hline
\end{tabular}


Table 2. Cont..

\begin{tabular}{|c|c|c|}
\hline Priority of Agritourism Offer & $\begin{array}{l}\text { Diversification Activities/ } \\
\text { Functional Relationship }\end{array}$ & $\begin{array}{c}\text { Main Relevance for Case } \\
\text { Studies (CS) }\end{array}$ \\
\hline $\begin{array}{c}\text { Enabling experiences with farm } \\
\text { activities }\end{array}$ & $\begin{array}{ll}- & \text { Livestock observation } \\
- & \text { Accompanying farm management } \\
\text { - } & \text { Farm life rhythm and } \\
\text { - } & \text { Dependence on nature and } \\
& \text { seasonal cycles } \\
\text { - } & \text { From raw products to farm } \\
& \text { produce, etc. }\end{array}$ & CS 1,3 \\
\hline $\begin{array}{l}\text { Cooperation with other sector } \\
\text { activities }\end{array}$ & $\begin{array}{ll}\text { - } & \text { Local sectors, e.g., crafts } \\
\text { - } & \text { Wood and non-wood forest products } \\
\text { - } & \text { Recreational sector and other } \\
& \text { tourism activities } \\
\text { - } & \text { Social services }\end{array}$ & CS 2,3 \\
\hline Linkages to outdoor activities & $\begin{array}{ll}\text { - } & \text { Base to outdoor activities } \\
\text { - } \quad \text { Interrelation of farm management to } \\
\text { nature protection } \\
\text { - } \quad \text { Education for activities }\end{array}$ & CS 2 \\
\hline Linkages to nature tourism & 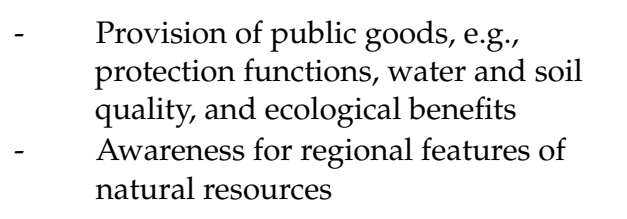 & CS 1 \\
\hline Addressing landscape features & $\begin{array}{l}\text { - } \quad \text { Linkages of farm management to } \\
\text { landscape features } \\
\text { - } \quad \text { Understanding effects of farm } \\
\text { management and abandonment }\end{array}$ & CS $1,2,4$ \\
\hline $\begin{array}{l}\text { Focus on farm-related } \\
\text { activities/events }\end{array}$ & $\begin{array}{ll}- & \text { Animal exhibits } \\
- & \text { Hands-on farm chores } \\
- & \text { Courses linked to wildlife experiences }\end{array}$ & CS $2,3,4$ \\
\hline
\end{tabular}

\section{Results}

\subsection{Diverse Contexts of Mountain Regions}

In many parts of the world, mountain regions have been included into human settlements quite early in historical perspective. This is linked to place-specific features of settlement development, but reflecting the evolving human-nature relationship. With demographic changes and the technological development of agricultural production, movements and extension of settlement areas toward mountain spaces that were previously not included in settlement became widespread. As mentioned, the time and pace of these changes are strongly related to spatial demographic, economic, and political contexts that have tremendously changed in history [35]. The settlement of large parts of the Alps can be observed throughout various periods of the Middle Ages. In general, this contributed to the shift of cultural spheres and exchange, as well as areas of retreat (over longer 
periods). In many cases, and particularly in the Alps, settlement and evolving land management were shaped by dependence on power relations and property rights, often depicting 'feudal' systems that assigned decision on land and its management to a small group of powerful people (c.f. for the Austrian Alps, [36]). Up to the present time, these historic foundations characterize settlement structures and land management patterns, even if socio-economic conditions have altered drastically. To some degree, cultural elements related to the past land management practices dispose of significant elements of attraction for agritouristic use.

In current China, villages include natural villages and administrative villages. A natural village is a natural settlement that has been formed by villagers who live together for a long time, and is the most basic component of rural settlements. The administrative village is the lowest level in China's administrative regionalization system, which is usually composed of a large natural village or several natural villages, and is run by a villagers' self-governing body such as a villagers' committee or a village office. To a much higher extent than in the Austrian Alps, mountain villages are located in deeply remote areas in high mountains where accessibility is very much restricted. Settlement in those regions was driven by villagers who fled to the mountains to escape from conflicts and combats in other regions and strict government administration. In effect, this led partly to a higher population share and more villages in Chinese mountains, which is expressed by considerably high population density levels for mountain contexts (e.g., about 270 inhabitants per $\mathrm{km}^{2}$ in mountains of Bijie in Guizhou province, see [18]). However, also in these remote areas, many cultural expressions are visible and nowadays could provide elements of attraction for agritouristic use.

The long experience on agritouristic activities in the Alps highlights the significant differences between European and Chinese mountain contexts with regard to farm management systems and the related tourist facilities. The strengths of rural mountain communities are seen particularly in its heritage quality and the integrity of the tourism offer, which are often visible through traditional livestock patterns, inspiring economic premises and a close link to the specific territory, and a strategic rejection of mass tourism [18,37]. While some of these aspects are of similar influence in mountain regions of China and underline the relevance of entrepreneurial perspectives, the community approach, and appropriate governance structures for success in agritourism development [38], these studies address the initial stage of the application of the concept of agritourism and the requirement to integrate social changes and environmental consequences. Despite the rapid development of different types of rural tourism, including agritouristic activities, in China, understanding of the core issues, development options, and opportunities for cooperation and networking seem to be limited and require further in-depth analyses [39].

\subsection{Approaches to Cope with Rural Labor Outflow}

As argued above, out-migration from mountainous regions is widespread; however, quite different developments are experienced across Europe and China [8]. As shown in Table 2, there are a wide variety of opportunities to engage in agritourism. The recent concern in China for rural values and the interest in farm-linked activities led to a rise in place-specific initiatives. The following selected examples address specific features and highlight some of the potential for increasing this form of rural tourism.

While case 1 (Huangdu village, Box 1) represents a successful example of agritourism development in a mountain region of China driven by farm produce enhancement (white tea), the second example (Lujia village) mainly builds on community-based development (Box 2). The two are located in the same province and thus underpin the variety of options and need to search for place-sensitive strategies. Case 3 (Daicum village) is a much larger investment and regional effort developed around a "National Agricultural Park" (Box 3). Its success is much more linked to the uptake of new technological opportunities and a rise in local employment, which have changed the traditional features of the village substantially. With regard to the concept of agritourism, this last case overlaps significantly with other 
rural tourism features. It highlights that cultural understandings of farm activities and agritourism boundaries largely differ between European and Chinese practices.

Box 1. Case study Huangdu village.

\begin{tabular}{l} 
Rural model of mountainous area \\
Development experience of Huangdu Village, Xilong Township, Anji County, Zhejiang Province ([40-42]). \\
Huangdu village, $11.5 \mathrm{~km}^{2}$, six natural villages, 423 farmers with a population of 1516 is one of the poorest \\
villages in Anji County. In order to obtain wealth, village officials led the villagers to run bamboo production \\
enterprises, wire drawing factories, iron casting factories, etc., to plant red bamboo, pepper, chestnut, bayberry, \\
and chrysanthemum. However, there has never been a desire to "get rich". Since the large-scale planting of \\
white tea in 1997, the per-capita annual income of the villagers had increased from 400 yuan (about $\$ 47)$ in 1997 \\
to more than 10,000 yuan (about $\$ 1176)$ in 2003 . Today, running the tea garden of more than 3200 ha, the villagers \\
accept the white tea industry as the leading factor and combine it with rural tourism development. With its \\
unique scenery of thousands of acres of tea gardens, and various tourism programs such as farm experience, \\
colorful outdoor leisure activities, and "tent" hotels, the village has become an excellent destination for leisure \\
travel and holiday. The village's output value exceeds 400 million Chinese Yuan (about $\$ 61.5$ million), and the \\
per capita annual income was more than 36,000 yuan ( $\$ 5538)$ in 2018 . \\
Today, Huangdu not only sells white tea, but also sells the tea landscape and tea culture, striving forward by \\
making use of the integration of the three products. Their cultivars cover nearly 200,000 ha in 18 provinces. \\
\hline
\end{tabular}

Box 2. Case study Lujia village.

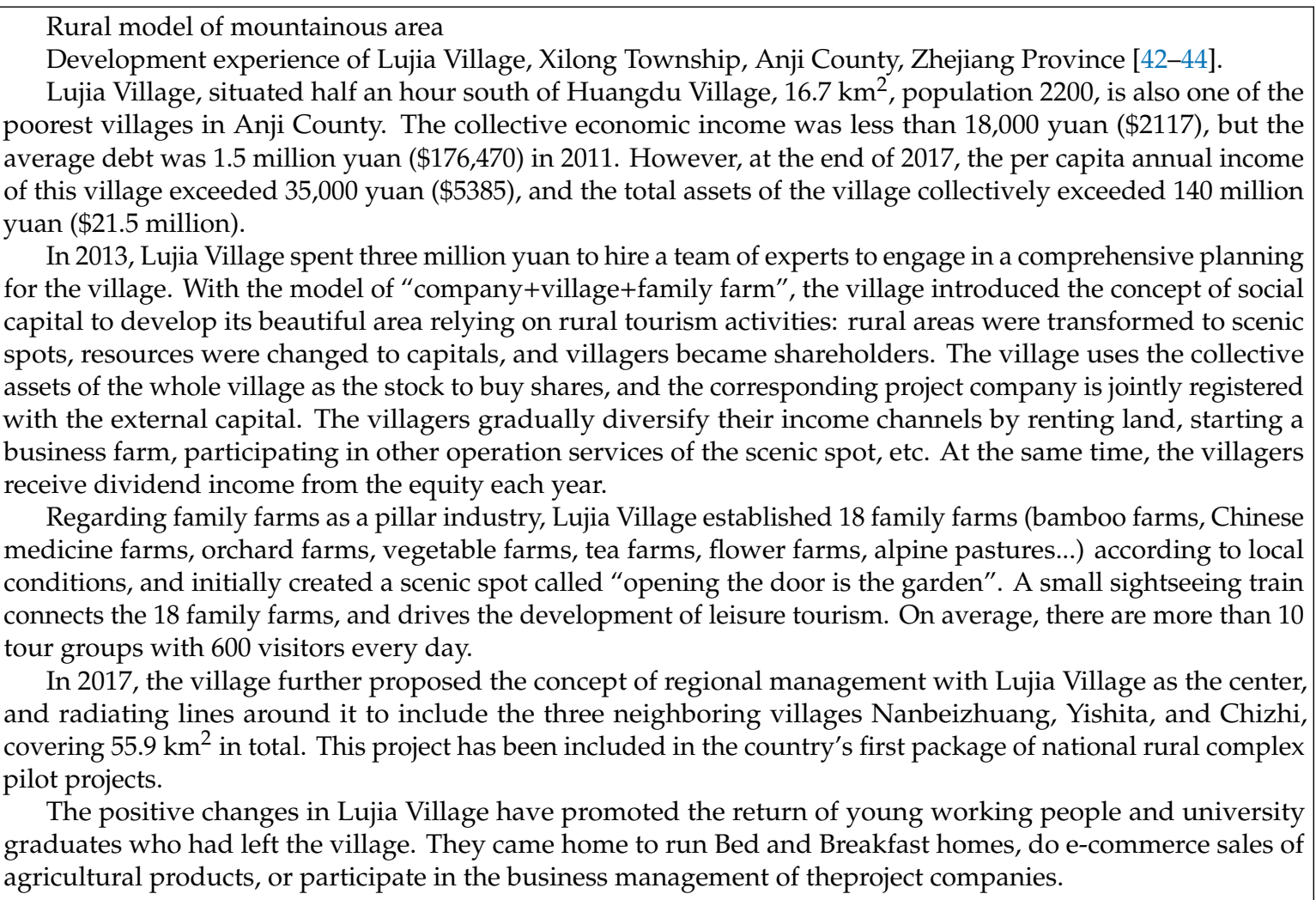


Box 3. Case study Daicun village.

\begin{abstract}
Lowland development model
Development experience of Daicun Village in Lanling County, Shandong Province ([45]):

At the beginning of 1999, Daicun was poor, and the collective debt of the village was over $\$ 0.48$ million (the income of a professor was about $\$ 300$ in China at that time). However, a new mission was approved: "Born in the countryside. Grow in the countryside. Take root in the countryside". The new village leader, Mr. Wang, began to explore the ways of large-scale modern agriculture. Under the guidance of experts, all the land was centralized, and joint-stock large-scale operation was carried out. Experts were invited to design and build a first-class modern agriculture demonstration park in China, which became a rural complex integrating agricultural science and technology demonstration, seed and seedling cultivation, industrial incubation, and leisure agriculture.

In 2012, the first pilot project, the "National Agricultural Park" was established with the approval of the Ministry of Agriculture and the National Tourism Administration. The project covers a total area of 1300 ha, with an investment of $\$ 150$ million, and now receives more than one million tourists annually. At the same time, over 200 training courses for over 100,000 farmers have been held here.

There are agricultural companies, tourism companies, and shopping malls in the village. Every villager and every family will find their own suitable job and development opportunities. Villagers can also develop and start businesses according to their own characteristics, skills, and wishes.

This thousand-year-old village thrives due to the development of multiple industries. The old debts could be paid off within a few years, and the village wealth has been growing day by day. In 2017, the total output value of all the industries in the village was more than $\$ 310$ million, and the village collective operation profit was $\$ 17$ million. The per capita net income of villagers increased from about \$170 in 1999 to $\$ 9500$ in 2017.

The development of Daicun has brought more and more benefits to the villagers and gradually solved the problems of employment, education, medical treatment, endowment, and housing. Villagers moved into their houses from dilapidated mud houses, and all people over 60 years old live in well-equipped "senior apartments", and enjoy "senior pensions". All the villagers have been paid by the village to participate in the "New Rural Cooperative Medical Scheme" and "New Rural Social Security Scheme" programs. The village also provides financial aid and scholarships for all children from primary school to university level. At the same time, the traditional culture of the village is also carried forward, in which "The village has changed, the farmers have become richer, the life has been better than ever before, and the attraction has become more and more." At present, although there are only about 3600 villagers in Daicun, there are more than 4000 workers commuting to the village from other places. More than 200 university graduates either come back home to the village to run their own businesses or are recruited by the village.
\end{abstract}

The last example, case study 4 (Baili Dujuan scenic area), points to a further aspect, i.e., reference to a specific plant (Box 4). This raises issues of regional protection, landscape development, and the influence of these features on agritourism demand. While this example uses aesthetic value as the decisive element for agritourism, this also holds an important part in many other agritourism activities. 
Box 4. Case study Baili Dujuan scenic area.

\begin{abstract}
Development model of preserved scenic area
Development experience of “Baili Dujuan" Scenic Area, National Park in Guizhou Province ([46]):

The flowering of rhododendron ("Dujuan") is the leading asset in the area. The Baili Dujuan Scenic Area was established in 1987. The core natural landscape is the primeval forest of rhododendron, the only park area of this type in China, stretching over $125.8 \mathrm{~km}^{2}$. There are more than 60 species of rhododendrons, accounting for six out of nine subgenera of the world's rhododendrons. A variety of rhododendron blooms in spring, their flowers lasting several weeks, and covering the mountains. Beili Dujuan is organizing the Rhododendron Festival from March to May every year. The opening ceremony of the Rhododendron Festival is arranged in general during the period when about a quarter of rhododendrons bloom. The news media, travel agencies, and special guests are invited to the ceremony, and visitors are invited to enjoy the flowers through a variety of media. Due to the attractive asset and the festival organization, the Baili Dujuan area has won numerous awards in the last 20 years and its tourist destination image has been continuously improved.

The characteristics of the seasonal flowering of rhododendrons cause Baili Dujuan serious problems related to a seasonal tourist offer. For several years, Baili Dujuan has been promoting complementary activities of agricultural tourism and the brand of flower-enjoying destinations by supporting the local farmers (representing a local minority group) to grow other economic flowers and fruit trees that bloom in different seasons. Such instruments have secured the flow of tourists for longer periods of the year, generating also substantial benefits to other local industries and farmers.

This involved the creation of the Yishan Flower Valley, which is a modern leisure and sightseeing agricultural demonstration park (using a total investment of 99.3 million CNY, about 15 million USD), the creation of a Damask rose garden of 133 ha, an American crape myrtle garden of 200 ha, and a Dahlia leisure-sightseeing zone and a free picking pear garden, each 13 ha, technically supported by the Hunan Academy of Forestry. All these activities enlarge the potential tourism season of the region, increasing experience options in the area, and raising income levels. Thus, "flower viewing" has become an attractive element in this area and impacted on the development of the cultural landscape.
\end{abstract}

Even if these case reports do not provide calculations on migration shifts, they underline the changes in the regional strategies. Action focusing on local initiatives aimed at mitigating out-migration has gained relevance. The most relevant factors to impede outflow comprise the following ones:

Native culture and customs (parents do not travel far, clan culture), hard-working, relatively closed vision, high satisfaction with the status quo of living conditions, and local options are at the core of 'rural tradition'.

This translated into a limited willingness of rural people to leave their regions, leading to, e.g., problems with factory recruitment (in the industrialization process starting in the 1950s).

The household registration policy has the effect of inhibiting movements and is an administrative obstacle to migration: for the efficient management of the people, for a long time, the household registration has been used to restrict the migration from other places, especially from rural areas to cities, or small cities to relatively large cities ('hukou' system; [47]. Farmers are confined to retain their living place in the countryside. Education upgrading was eventually the common way, if not to say the only way, for young people to leave the countryside.

On the other hand, a series of important factors add to the motivation to find living places in other regions and strongly drive outflow from mountain regions, including excess labor, low income levels and disparity regarding urban income opportunities, the desire for urban life, material progress, and health and social security guaranteed to a higher extent in urban contexts, and higher benefits for agricultural activities in non-mountainous areas. Moreover, in historical times, cultural changes and the deprivation of the farming population incited many peasants of mountain regions to migrate either to neighboring countries (such as Swiss farmers migrating to neighboring mountain areas in Vorarlberg in Austria [48] or to non-mountainous or even far away regions, such as to the Americas, particularly driven by severe poverty and desire to start a "new living" under quite different conditions. 


\subsection{Contributions and Challenges of Rural Labor Outflow to Societal Development}

Out-migration from mountain regions is not just a spatial phenomenon; instead, it inherently addresses social development. Local changes to land management and employment developments are closely linked to cultural features. Tourism, and particularly agritourism, has a pivotal role on spatial changes, landscape development, and cultural changes, which opens up opportunities to shape these processes. A series of important (positive) contributions of labor movements (such as coping with a lack of manpower for industrial development and social services) have to face opposing severe problems for the society in mountain regions, which have to be taken into account when elaborating strategies for agritourism initiatives:

- A detrimental effect on the existing municipalities and the spatial structures of these mountain municipalities.

- The disappearance of 'rural homeland' culture, which is particularly important for China as a large agricultural country that has lasted for thousands of years.

- Taking away options of next generations: the problems of rural left-behind children (LBC) are mainly the matter of their psychological and personality distortion. Although a government report indicates that their number is decreasing due to the open policies that allow the rural children to go to the city with their parents, this issue should not be neglected [49].

- Impact on social security and self-esteem: awareness of severely restricted future options, inequality in society, and a new generation of psychologically and temperamentally distorted rural people.

- Affecting social service provision: in particular, decreasing population impacts on the potential to secure public services, in particular (quality) education in rural mountainous regions.

Accelerated changes in land management also lead to negative environmental performance. Even already in earlier stages of the process, a change in land management and a decrease in the utilization rate of land and its resources might cause outflow, altered perceptions on regional opportunities and assets, and lead to environmental consequences with negative impacts. In the context of climate change, these processes tend to gain in relevance, and change processes might gain in speed. Moreover, changes in the use of natural resource uses and their aesthetical appearance, as expressed through landscape changes, would directly impact on tourism attractiveness and the capacity to apply agritourism strategies in such mountain areas.

\subsection{Factors of Rural Labor Outflows in Mountainous Areas}

From the case studies and respective studies $[3,8,33,50,51]$, the focus of regional strategies on geographical specificities and mountain-specific assets can be derived. This calls for a place-based approach in policy design, as conditions and spatial trends are very diverse. Following analysis in the Alps, detailed observations at fine geographical scales suggest great variations in territorial response. Moreover, for more than two decades, mountain regions in large parts of Western Europe have shared changes in migration movements, i.e., an increase in immigration from abroad due to international movements and flows toward (Western) European countries. As a consequence, most mountain regions show a positive migration balance of international movements, but in many cases, they show a national negative one [52].

Major catalysts for movements are based on industrialization, urbanization, and agricultural modernization processes, which led to the gradual disappearance of traditional villages. Moreover, urbanization trends implied that the urban population is steadily increasing and has exceeded the rural population at the global scale, as well as in China, and in many mountain regions, trends of urbanization can be observed in a similar way.

However, with regard to these overarching trends, we recently observed a rise in countercurrent factors that might provide aspects for future strategies to cope with the imminent demographic 
challenges and simultaneously consider the opportunities and needs of local population and societal demands. The main aspects involved are:

- Social dependence on agriculture: No matter how the society develops, agriculture is a precondition for life (a 'must') that shapes landscapes, impacts settlement structures, and generates food provision and security. For China, as a country with a large population, it is essential to secure land management and food security by sustaining development options for adapted farming systems.

- The need to maintain rural culture: The countryside is the foundation of Chinese traditional culture. Traditional villages retain rich and colorful cultural heritage. They are important vehicles for carrying and embodying the traditional civilization of the Chinese nation, which are aspects that have been shaped over long periods in historic times.

- China's current policies: Rural household registrations are permitted to build their own houses. Many city residents now try to own or retain rural household registration (then, they can build their own houses, while otherwise they would only be able to buy condos from real estate developers), owing to the traditional Chinese desire to own a house and appreciate the attractive living conditions in the countryside.

- Future of labor market development: The demand for low-skilled labor will be reduced in the future, and issues of high-level education will gain in importance. Matching education and employment skills will become a rising challenge, and territorial specificity and attractiveness will add to these challenges.

- Return migration: Many farmers working in cities have broadened their horizons and ideas, accumulated start-up funds, and returned to their hometowns, using the unique environment and conditions of the countryside to start new businesses. An increasing number of good practice examples exist throughout the world, with strong emphasis on achievements in Alpine areas (see [50]), but there are also emerging examples throughout China's mountain areas (Mr. Wang Chuanxi, the village head of Daicun Village, see Box 3; and Mr. Wei Jia, an undergraduate going back to his home, Huangdu Village, see Box 1).

\subsection{Findings and their Relevance for Future-Oriented Development}

A key constraint is the question of how to realize the transformation and development of China's mountainous rural areas. Comparing the situation with the Alps, lessons might be drawn from the transformation of traditional villages and agriculture activities toward a mosaic pattern of economic activities and living spheres. Yet, challenges remain high, and ongoing studies reveal the scope of divergent options and considerable choices available to local and regional actors. The prospective study on the future of the Alps in 2050 provides ample indications for decision points and the transformation of social, economic, and social pathways [53]. With regard to mountain regions experiencing or threatened by long-term out-migration, further analyses of changing strategies are required in order to realize the design and implementation of transformation at various levels (including fine geographical ones).

The inclusion of the development of the tertiary sector, i.e., a focus on service sector employment might be of specific benefit for mountain regions. It holds a strong opportunity for land management and the linking of activities of agricultural actors and other local sectors. Agritourism activities, such as those long-established in the Alps, also hold significant potential for mountain regions of China. The case studies (see Boxs 1-4) are illustrations for exemplary approaches of numerous and very diverse initiatives across these mountain contexts. All of them underpin place-based opportunities that were not visible at first sight, but which had been addressed and nurtured through the initiative of innovative people and/or strategies and programs. The cases underscore territorial legacies, cultural influences, and the diversity of community approaches, which reveal significant differences in actual application to the Alps, even if conceptual lessons are of high interest. 


\section{Discussion}

From the analysis of movements of mountain populations and the basic contribution of mountain farming to the functions of mountain regional development, it seems important to address the specific assets of mountains as an inherent value. Case study 1 (Huangdu village) exemplifies the need for incorporating tourism development in a comprehensive regional approach. In particular, many of those assets and activities are closely linked to the land management, food, and valuation of landscapes, thus underpinning the scope for agritourism action. Many studies $[2,3,16,30,54]$, development manuals $[22,33,34]$, and practice reflections $[17,19,21,29]$ point to the pivotal role of detecting specificity, identity, and valorization aspects that are meaningful for both the local population and visitors. Developing a rural (mountain) tourism strategy that takes advantage of these features relates also to the general development of the tertiary industry, which has a direct impact on job creation and regional economic performance. In this regard, there is a long and intensive experience within Alpine mountain tourism, and particularly agritourism business $[17,19,22]$ that could be used as examples for other mountain regions around the world, in which key aspects might serve as "transfer knowledge" for mountain development in China [24]. With the large population of China's mountain areas and rising demand, there is big scope for developing appropriate agritourism activities.

This approach requires a joint perspective and action plan for developing agriculture (place-adapted land management of agricultural and forest areas) and tourism business planning. This might be inspired by experiences drawn from the resort industry in the Alps, and more specifically activities linking agriculture and tourism activities through agritourism concepts, which can face the place-specific challenges and address opportunities of mountain development [21,22].

Building on the repertoire of empirical knowledge, agriculture and tourism need to be integrated into a new agritourism system industry [51]. This combination requires a redefinition of agricultural tourism that focuses on the future sustainable development of the Chinese countryside (referring to the history and insights from activities in the Alps). Core activities would include:

- Understanding and fostering the variety of multi-faceted approaches to suit the interests and needs of various groups of local people (all case studies).

- Redefining agritourism as a systematic engineering: agriculture is designed for tourism and supporting tourism as well as its original basic functions (see case 2).

- Enabling the complementary functions of agriculture and tourism to support and promote each other in order to achieve the required contribution to 'sustainable' development (see case 4).

- Enhancing the transformation of the economic efficiency of rural smallholders to agricultural companies by addressing place-based options of product development, niche product development, regional and high-quality labeling focus, and diversification activities that link natural resource use with increasing social demand for those kinds of (highly valued) products and services (see case 1).

- Establishing a comprehensive linkage chain of sectoral activity, local anchoring, and diversification of family farms based on social capital development (see case 2).

- Linking farm tourism activities with local tourism attractions (see case 3) to broaden the scope of attractive elements and increase demand for these agritourist offers.

The specific features of agritouristic activities that are based on local traditional assets, social capital, and institutional frameworks tend to reflect the diversity of agritourism between the observed areas. The natural resource base and heritage protection consideration are some of the greatest assets in this respect. However, we should be aware that severe conflicts between heritage protection strategies and the pursuit of modern lifestyles [55] might affect the implementation and turn into substantial challenges for agritourism activities. 


\section{Conclusions}

The paper explores the potential of enhanced agritourism activities in the context of regions that have been affected by population decline for many years. While this situation has been a prominent issue in the Alps, and countries such as Austria put a strong emphasis on diversifying activities of land management toward other activities, the outflow of mountain population, and particularly young people is a more recent phenomenon in China. Consideration and analysis of the history of land management, challenges, opportunities, and scope for tourism and agritourism concepts to cope with rising regional problems are addressed for both spatial contexts and, to some extent, a comparison indicates lessons for future strategy building and action development. Even if no figures on changes in the migration trends could be provided through the cases explored, the exploration of the Chinese cases emphasizes two further aspects: a strategic concept for agritourism development needs to consider its role in tourism at the time when planning agricultural development. This is an additional perspective that goes beyond the European model that is primarily based on historical structures and conveys less scope to planning devices (so far). The second issue is partly discussed in Europe as well, i.e., the issue of cooperation. In China, the focus is on community development in the form of the cooperation of a whole village, which is regarded as essential to establish agritourism activities, as highly efficient and sustainable rural tourism is not shaped just by individual events, but more importantly requires a whole setting of the environment and the place-specific atmosphere.

For a long time, Austria (similar to other regions of the Alps, e.g., Italian Alpine regions) has engaged in widespread agritourism activities, enhancing a small-scale tourism operation. This model builds on the specific agricultural and business structure of these regions. It favors family enterprises and linked agricultural and tourism operations. The application of this approach throughout the country has led to a situation where about $1 / 10$ of the overall tourism activity is linked to agritourism in a very intensive tourism setting. The main success factors are linked both to structural features and the asset base, which is characterized by mountain amenities that are highly appreciated within the national society and at the international level as well [56]. Although mountain agritourism is just a minor economic sector in the overall regional economy, it is remarkable that this activity builds on and nurtures the attractiveness of the area, thus indirectly contributing to mitigating out-migration, and respectively increasing pull factors for immigrants. A thorough survey of the effects of the agritourism business across Austria's mountain areas is not at hand, but action plans and rising awareness of these linkages underpin the relationships addressed.

There is rising concern for these issues in the context of the mountain regions of China, which are affected by a particularly strong urbanization process, structural changes, and commitment to new approaches and developing models, including agritourism activities. The specificity and the high diversity of regional situations in China prevent a standard application and underline the differences from the European context. Nevertheless, the case studies presented valid points to three major issues for the conceptual development of agritourism in this country: (i) addressing the amenity value and landscape features as an attractive element to conceive fruitful agritourism activities; (ii) engaging in a comprehensive planning process that links the various actors and business levels in the cross-sector activities; and (iii) integrating specific local tourism attraction elements, as drivers for attracting and supporting more local organized small-scale agritourism business activities. Such a strategy could underscore the great interest in rural tourism in China [57] with about a third of tourists heading to rural regions, which means an estimated two billion rural visits by 2020. This provides a substantial scope for agritourism development.

Experience from both mountain contexts underpins the need to appreciate natural and cultural heritage as the basis of agritourism and the need for a carefully conceived business development. Agritourism might take a particularly important role in heritage preservation [58] since natural and cultural heritage features provide core attractions for this tourism type, and thus could "serve as the basic foundation for agritourism" [1,59], which is quite often visible in the increased valuation of traditional rural landscapes and nature protected areas through agritourists' preferences [60]. These 
can be used for strategies to enhance the competitiveness of tourism destinations in heritage-rich regions [61]. These reflections on the core influence of heritage aspects on agritourism development options highlight that it is not so much dependent on "optimal" planning devices, but rather on the long-term commitment of local actors, a deep cultural connotation of the selected strategies [62], national appreciation, and support and stable structures for enhancing social capital formation in these mountain areas.

Author Contributions: Conceptualization, T.D. and D.Z.; Investigation, Y.C.; Methodology, D.Z.; Project administration, T.D. and D.Z.; Validation, D.Z.; Writing—original draft, T.D. and D.Z.; Writing—review \& editing, Y.C. and T.D.

Funding: This research received no external funding. The APC was funded by the Federal Institute of Agricultural Economics, Rural and Mountain Research, Vienna (Austria).

Acknowledgments: Authors gratefully acknowledge support given by Marco Onida, then General Secretary of the Alpine Convention during the field visit to the countries of the Alpine mountain range and for information on the wide range of agritourism initiatives in that area. Moreover, the present article could integrate valuable comments provided by participants at the presentation of a former version of the article at the First World Congress on Agritourism in Bozen/Bolzano, Italy, 7-9 November 2018.

Conflicts of Interest: The authors declare no conflict of interest.

\section{References}

1. Organization for Economic Co-operation and Development (OECD). OECD Tourism Trends and Policies 2018; OECD Publishing: Paris, France, 2018.

2. Lane, B.; Kastenholz, E. Rural tourism: The evolution of practice and research approaches-towards a new generation concept? J. Sustain. Tour. 2015, 23, 1133-1156. [CrossRef]

3. Marsat, J.B.; Menegazzi, P.; Monin, C.; Bonniot, A.; Bouchaud, M. Designing a Regional Policy of Agrotourism-The Case of Auvergne Region (France). Eur. Countrys. 2013, 5, 308-321. [CrossRef]

4. Streifeneder, T. Agriculture first: Assessing European policies and scientific typologies to define authentic agritourism and differentiate it from countryside tourism. Tour. Manag. Perspect. 2016, 20, 251-264. [CrossRef]

5. Eurac Research. Outcome Statement. In Proceedings of the 1st World Congress on Agritourism, Bozen-Bolzano, Italy, 7-9 November 2018; Available online: https://agritourism.eurac.edu/wac/wac2018/ WAC_2018_Outcome\%20Statement_A4.pdf (accessed on 24 June 2019).

6. Lu, D.; Liu, Y.; Lai, I.; Yang, L. Awe: An Important Emotional experience in Sustainable Tourism. Sustainability 2017, 9, 2189. [CrossRef]

7. Kazig, R. Landschaft mit allen Sinnen-Zum Wert des Atmosphärenbegriffs für die Landschafts-forschung. In Landschaften: Theorie, Praxis und International Bezüge; Bruns, O., Kühne, O., Eds.; Oceano: Schwerin, Germany, 2013; pp. 221-232.

8. Gløersen, E.; Price, M.F.; Borec, A.; Dax, T.; Giordano, B. Cohesion in Mountainous Regions of the EU—Research for REGI Committee. European Parliament, Directorate-General for Internal Policies, Policies Department B: Structural and Cohesion Policies, Regional Development; IP/B/REGI/IC/2015_175; European Parliament: Brussels, Belgium, 2016; Available online: http://www.europarl.europa.eu/RegData/etudes/STUD/2016/573420/IPOL_STU\% 282016\%29573420_EN.pdf (accessed on 26 April 2019).

9. Gerhardter, G.; Gruber, M. Regionalförderung als Lernprozess, Evaluierung der Förderungen des Bundeskanzleramtes für Eigenständige Regionalentwicklung; Schriften zur Regionalpolitik und Raumordnung 32; Bundeskanzleramt: Wien, Austria, 2001.

10. Gløersen, E.; Dragulin, M.; Hans, S.; Kaucic, J.; Schuh, B.; Keringer, F.; Celotti, P. The Impact if Demographic Change on European Regions; European Union, Committee of the Regions: Brussels, Belgium, 2016.

11. Liu, Y.; Li, Y. Revitalize the world's countryside. Nature 2017, 548, 275-277. [CrossRef] [PubMed]

12. National Bureau of Statistics of China. Communique on the Main Results of the Second National Census of Basic Units in China. 22 January 2003. Available online: http://www.stats.gov.cn/enGlisH/NewsEvents/ 200303/t20030312_25984.html (accessed on 26 April 2019).

13. National Bureau of Statistics of China. Third National Agricultural Census; National Bureau of Statistics of China: Beijing, China, 2017. 
14. Dax, T.; Fischer, M. An alternative policy approach to rural development in regions facing population decline. Eur. Plan. Stud. 2017, 26, 297-315. [CrossRef]

15. ESPON. Shrinking Rural Regions in Europe, towards Smart and Innovative Approaches to Regional Development Challenges in Depopulating Rural Regions; Policy Brief ESPON EGTC: Luxembourg, 2017.

16. Debarbieux, B.; Oiry Varacca, M.; Rudaz, G.; Maselli, D.; Kohler, T.; Jurek, M. Tourism in Mountain Regions: Hopes, Fears and Realities; Sustainable Mountain Development Series; UNIGE, CDE, SDC: Geneva, Switzerland, 2014.

17. Euromontana. Background paper on sustainable mountain tourism. In Proceedings of the Conference "Sustainable Active Tourism-Mountain Communities Leading Europe in Finding Innovative Solutions", Inverness, UK, 27-28 September 2011; Available online: https://www.euromontana.org/wp-content/uploads/ 2014/07/2011_09_EM_backgroundpaper_Iverness.pdf (accessed on 24 June 2019).

18. Zhang, D.; Dax, T. Transition of mountain farming towards a stronger involvement of local population services in China. In Proceedings of the IAMO Forum 2013 “Rural Areas in Transition: Services of General Interest, Entrepreneurship and Quality of Life", IAMO and vTI, Halle, Germany, 19-21 June 2013.

19. Netzwerk Zukunftsraum Land. Tourismus und Landwirtschaft, Innovative Kooperationen und Strategien für die Zukunft. In Proceedings of the Innovative Werkstatt, St. Veit an der Glan, Austria, 24 May 2018; Available online: https://www.zukunftsraumland.at/veranstaltungen/9524 (accessed on 24 June 2019).

20. Barbieri, C.; Xu, S.; Gil-Arroyo, G.; Rozier Rich, S. Agritourism, Farm Visit, or ... ? A Branding Assessment for Recreation on Farms. J. Travel Res. 2016, 55, 1094-1108. [CrossRef]

21. WAC (World Congress on Agritourism). Outcome statement. In Proceedings of the First World Congress on Agritourism, Bolzano, Italy, 7-9 November 2018; Available online: http://agritourism.eurac.edu/wac/ wac2018/WAC_2018_Outcome\%20Statement_A4.pdf (accessed on 24 June 2019).

22. Urlaub am Bauernhof. 25 Jahre Urlaub am Bauernhof Österreich. Eine perfekte Verbindung von Tradition und Moderne; APA-OTS Tourismuspresse: Salzburg, Austria, 2018; Available online: https://www.tourismuspresse. at/presseaussendung/TPT_20160428_TPT0009/25-jahre-urlaub-am-bauernhof-oesterreich-bild (accessed on 26 April 2019).

23. European Parliament. EU Agenda for Rural, Mountainous and Remote Areas; European Parliament resolution of 3 October 2018 (2018/2720(RSP)), document P8_TA-PROV(2018)0374; European Parliament: Brussels, Belgium, 2018.

24. Dax, T.; Zhang, D.C. Strategien der Berggebietsentwicklung im Alpengebiet und im Berggebiet Chinas, Analyse von Lernprozessen der lokalen Entwicklung. Available online: https://www.bmnt.gv.at/dam/ jcr:794e6bb1-d947-40ea-8c4b-c85a90218aec/04_Dax_Zhang_Berggebietsentwicklung.pdf (accessed on 26 April 2019).

25. Dax, T. Why are Local Initiatives So Important in Mountain Regions? Available online: http://www.fs.fed.us/ psw/cirmount/publications/pdf/Mtn_Views_dec_15.pdf (accessed on 26 April 2019).

26. Copus, A.; Shucksmith, M.; Dax, T.; Meredith, D. Cohesion Policy for rural areas after 2013, A rationale derived from the EDORA project (European Development Opportunities in Rural Areas) ESPON 2013 Project 2013/1/2. Stud. Agric. Econ. 2011, 113, 121-132. [CrossRef]

27. Tew, C.; Barbieri, C. The perceived benefits of agritourism: The provider's perspective. Tour. Manag. 2012, 33, 215-224. [CrossRef]

28. Su, B. Rural tourism in China. Tour. Manag. 2011, 32, 1438-1441. [CrossRef]

29. Embacher, H. Marketing for Agri-tourism in Austria: Strategy and Realisation in a Highly Developed Tourist Destination. J. Sustain. Tour. 1994, 2, 61-76. [CrossRef]

30. Hummelbrunner, R.; Ernst Miglbauer, E. Tourism promotion and potential in peripheral areas: The Austrian case. J. Sustain. Tour. 1994, 2, 41-50. [CrossRef]

31. McGinnis, M.D.; Ostrom, E. Social-Ecological System Framework: Initial Changes and Continuing Challenges. Ecol. Soc. 2014, 19, 30. [CrossRef]

32. Nigmann, T.; Dax, T.; Hovorka, G. Applying a social-ecological approach to enhancing provision of public goods through agriculture and forestry activities across the European Union. Stud. Agric. Econ. 2018, 120, 1-7. [CrossRef]

33. Rozier Rich, S.; Tomas, S.; Coluci, S.; Komar, S.; Schilling, B.; Carleo, J. Agritourism Opportunities for Farm Diversification. Fact Sheet; North Carolina Cooperative Extension: Morganton, NC, USA, 2010. 
34. Vaugeois, N.L.; Bence, S.; Romanova, A. Farm Diversification Through Agri-Tourism: A Manual to Guide Development in British Columbia; British Columbia Ministry of Agriculture: Victoria, BC, Canada, 2017.

35. Price, M.F. Mountains. A Very Short Introduction; Oxford University Press: Oxford, UK, 2015.

36. Krammer, J.; Rohrmoser, F. Im Kampf um ihre Rechte. Geschichte der Bauern und Bäuerinnen in Österreich; Promedia: Wien, Austria, 2012.

37. Lun, L.-M.; Pechlaner, H.; Volgger, M. Rural tourism develoment in mountain regions: Identifying success factors, challenges and potentials. J. Qual. Assur. Hosp. Tour. 2016, 17, 389-411. [CrossRef]

38. Yang, M.; Hens, L.; Ou, X.; De Wulf, R. Tourism: An Alternative to Development? Reconsidering Farming, Tourism, and Conservation Incentives in Northwest Yunnan Mountain Communities. Mt. Res. Dev. 2009, 29, 75-81. [CrossRef]

39. Wang, L.; Cheng, S.; Zhong, L.; Mu, S.; Dhruba, B.G.; Ren, G. Rural tourism development in China: Principles, models and the future. J. Mt. Sci. 2013, 10, 116-129. [CrossRef]

40. Ding, Y. Huangdu Village of Anji County, Zhejiang-A Piece of Leaf Riches the Whole Region. Available online: http://www.sohu.com/a/238587562_99962390 (accessed on 26 April 2019).

41. Ren, X. Huzhou Adhered to 13 Years: Economic Development and Ecological Protection both Win-Win. Sina Finance, 2018. Available online: http://finance.sina.com.cn/roll/2018-04-19/doc-ifzihneq2031626.shtml (accessed on 26 April 2019).

42. Ye, P. The Legends of Two Mountain Villages in Anji, Zhejiang. China News Network, 2018. Available online: http://www.chinanews.com/sh/2018/06-30/8552484.shtml (accessed on 26 April 2019).

43. Li, R. Lujia Village, Anji, Zhejiang: Creating a Pastoral Complex to Help Integrate the Three Industries. Xinhuanet, 2017. Available online: http://www.xinhuanet.com//photo/2017-11/14/c_1121954143_5.htm (accessed on 26 April 2019).

44. Zhejiang Satellite TV. The Road to Revitalization of Lujia Village, Anji, Zhejiang: A 7-Year Change in a Village. 2018. Available online: https://baijiahao.baidu.com/s?id=1591830682078737122\&wfr=spider\&for=pc (accessed on 26 April 2019).

45. Shan Dong Culture. Embrace Nature at Lanling National Agricultural Park. 17 September 2018. Available online: http://www.chinadaily.com.cn/m/shandong/shandongculture/2018-09/17/content_36930789.htm (accessed on 26 April 2019).

46. Chen, Y.; Dax, T.; Zhang, D. Complementary Effects of Agricultural Tourism and Tourist Destination Brand in Resource-Preserved Scenic Areas, Comparative Findings from Mountain Case studies in China and Europe. In Proceedings of the 1st World Congress on Agritourism, Bozen-Bolzano, Italy, 7-9 November 2018.

47. Yeh, E.T.; O’Brien, K.J.; Ye, J. Rural politics in contemporary China. J. Peasant Stud. 2013, 40, 915-928. [CrossRef]

48. Häfele, E. Europäisch, Jung, Mobil-Neue Zuwanderung nach Vorarlberg 2008-2014; AK Vorarlberg: Feldkirch, Austria, 2015.

49. Beh, L.S. China's Left-behind Children: Development and Challenges for the Future. Cph. J. Asian Stud. 2014, 32, 58-83.

50. Dax, T. Neueste Entwicklungen und Erfolgsfaktoren der Ländlichen Entwicklung. In Berglandwirtschaft und Ländlicher Raum, Broschüre zur 4. Schwerpunktveranstaltung im Rahmen der Österreichischen Präsidentschaft der Alpenkonvention; BMLFUW: Wien, Austria, 2007; pp. 12-18.

51. McGehee, N.G. An agritourism systems model: A Weberian perspective. J. Sustain. Tour. 2007, 15, 111-124. [CrossRef]

52. Gretter, A.; Machold, I.; Membretti, A.; Dax, T. Pathways of Immigration in the Alps and Carpathians: Social Innovation and the Creation of a Welcoming Culture. Mt. Res. Dev. 2017, 37, 396-405. [CrossRef]

53. Chilla, T.; Heugel, A.; Streifeneder, T.; Ravazzoli, E.; Laner, P.; Tappeiner, U.; Egarter, L.; Dax, T.; Machold, I.; Pütz, M.; et al. Alps 2050 Common Spatial Perspectives for the Alpine Area. Towards a Common Vision; ESPON EGTC: Luxembourg, 2018.

54. Barbieri, C.; Mahoney, E.; Butler, L. Understanding the Nature and Extent of Farm and Ranch Diversification in North America. Rural Sociol. 2008, 73, 205-229. [CrossRef]

55. Wang, L.; Yotsumoto, Y. Conflict in tourism development in rural China. Tour. Manag. 2019, 70, $188-200$. [CrossRef]

56. Dax, T. Recognising the amenities of mountain agriculture in Europe. Mt. Forum Bull. 2009, 9, 3-5. Available online: http://www.mtnforum.org/sites/default/files/publication/files/2013.pdf (accessed on 26 April 2019). 
57. Travel Gumbo. Agritourism a Growing Trend in China. 2015. Available online: https://www.travelgumbo. com/blog/agritourism-a-growing-trend-in-china (accessed on 26 April 2019).

58. LaPan, C.; Barbieri, C. The role of agritourism in heritage preservation. Curr. Issues Tour. 2013, 17. [CrossRef]

59. Khamung, R. A Study of Cultural Heritage and Sustainable Agriculture Conservation as a Means to Develop Rural Farms as Agritourism Destinations. Humanit. Arts Soc. Sci. Stud. 2015, 15, 1-36.

60. Torquati, B.; Tempesta, T.; Vecchiato, D.; Venanzi, S.; Paffarini, C. The Value of Traditional Rural Landscape and Nature Protected Areas in Tourism Demand: A Study on Agritourists' Preferences. Landsc. Online 2017, 53. [CrossRef]

61. Lo, M.-C.; Mohamed, A.A.; Chin, C.-H.; Ramayah, T. The Impact of Natural Resources, Cultural Heritage, and Special Events on Tourism Destination Competitiveness: The Moderating Role of Community Support. Int. J. Bus. Soc. 2017, 18, 763-774.

62. Youxoue, J.; Shujin, W.; Tsai, C.-C. Study on the Consumption of Agritourism in China. In Proceedings of the International Conference on Service Science, Management and Engineering, Wuhan, China, 20-21 August 2016.

(C) 2019 by the authors. Licensee MDPI, Basel, Switzerland. This article is an open access article distributed under the terms and conditions of the Creative Commons Attribution (CC BY) license (http://creativecommons.org/licenses/by/4.0/). 